\title{
Computational modeling of Basal Ganglia: towards a mechanism of high frequency stimulation
}

\author{
Félix Njap ${ }^{1,2^{*}}$, Andréas Moser ${ }^{3}$, Simon Vogt ${ }^{1}$, Ulrich Hofmann ${ }^{1}$ \\ From Nineteenth Annual Computational Neuroscience Meeting: CNS*2010 \\ San Antonio, TX, USA. 24-30 July 2010
}

Deep Brain Stimulation(DBS) with $130 \mathrm{~Hz}$ represents an effective therapy to alleviate symptoms of some neurodegenerative diseases such as Parkinson syndrome [1]. However the mechanism underlying the observed improvement in patient's symptoms is still under dispute. Modeling of its mechanism was first done with the Albin-Delong [2] model, which assumed two discriminated feedforward projections, from the input stage Striatum to the output stage Globus pallidus internal (GPi) and Substantia Nigra pars reticulata (SNr). However, this influential contribution neither took motor control into account nor the evidence for a selective of effect high frequency stimulation [3-5]. This study tries to model the underlying network with increasing realistic complexity and presents a spiking network model based on Izhikevich type neurons [6]. Our currently simulated model examines the firing patterns variability between GABAergic STN neuron projections depending on the firing rate. It shows features like synchronous, rythmic population spike found in experimental data of pyramidal interneuronal network [7].

\section{Acknowledgement}

This work was supported by the Graduate School for Computing in Medicine and Life Sciences funded by Germany's Excellence Initiative [DFG GSC 235/1].

\footnotetext{
Author details

'Institute for Signal Processing, University of Lübeck, Lübeck, D-23538, Germany. ${ }^{2}$ Graduate School for Computing medicine and Life Sciences, Lübeck, D-23538, Germany. ${ }^{3}$ Department of Neurology, University of Lübeck, Lübeck, D-23538, Germany

Published: 20 July 2010

* Correspondence: njap@isip.uni-luebeck.de

'Institute for Signal Processing, University of Lübeck, Lübeck, D-23538, Germany
}

\section{References}

1. Obeso JA, Olanow CW, Rodriguez-Oroz MC, Krack P, Kumar R, Lang AE: Deep-brain stimulation of the subthalamic nucleus or the pars interna of the globus pallidus in Parkinson's disease. N Engl J Med 2001, 345:956-63.

2. Albin RL, Young AB, Penney JB: The functional anatomy of basal ganglia disorders. Trends Neurosci 1989, 12:366-375.

3. Hiller A, Loeffler S, Haupt Ch, Litza M, Hofmann U, Moser A: Electrical High Frequency Stimulation Induces GABA Outflow in Freely Moving Rats. J Neurosci Methods 2007, 159:286-290.

4. Li T L, Thümen A, Moser A: Modulation of a neuronal network by electrical high frequency stimulation in striatal slices of the rat in vitro. Neurochem. Int. 2006, 48:83-86.

5. Mantovani M, Haas CA, Zentner J, Moser A, Feuerstein TJ: GABAA autoreceptors enhance GABA release from human neocortex: towards a mechanism for high-frequency stimulation (HFS) in brain.

6. Izhikevich EM: Simple model of Spiking Meurons. IEEEE Transact. Neural Netw 2003, 14(6).

7. Börgers C, Kopell N: Synchronization in Networks of Excitatory and Inhibitory Neurons with Sparse, Random connectivity. Neural Comput 2003, 15:509-538.

doi:10.1186/1471-2202-11-S1-P113

Cite this article as: Njap et al:: Computational modeling of Basal Ganglia: towards a mechanism of high frequency stimulation. BMC Neuroscience 2010 11(Suppl 1):P113.
Submit your next manuscript to BioMed Central and take full advantage of:

- Convenient online submission

- Thorough peer review

- No space constraints or color figure charges

- Immediate publication on acceptance

- Inclusion in PubMed, CAS, Scopus and Google Scholar

- Research which is freely available for redistribution

Submit your manuscript at www biomedcentral com/submit
C Biomed Central 